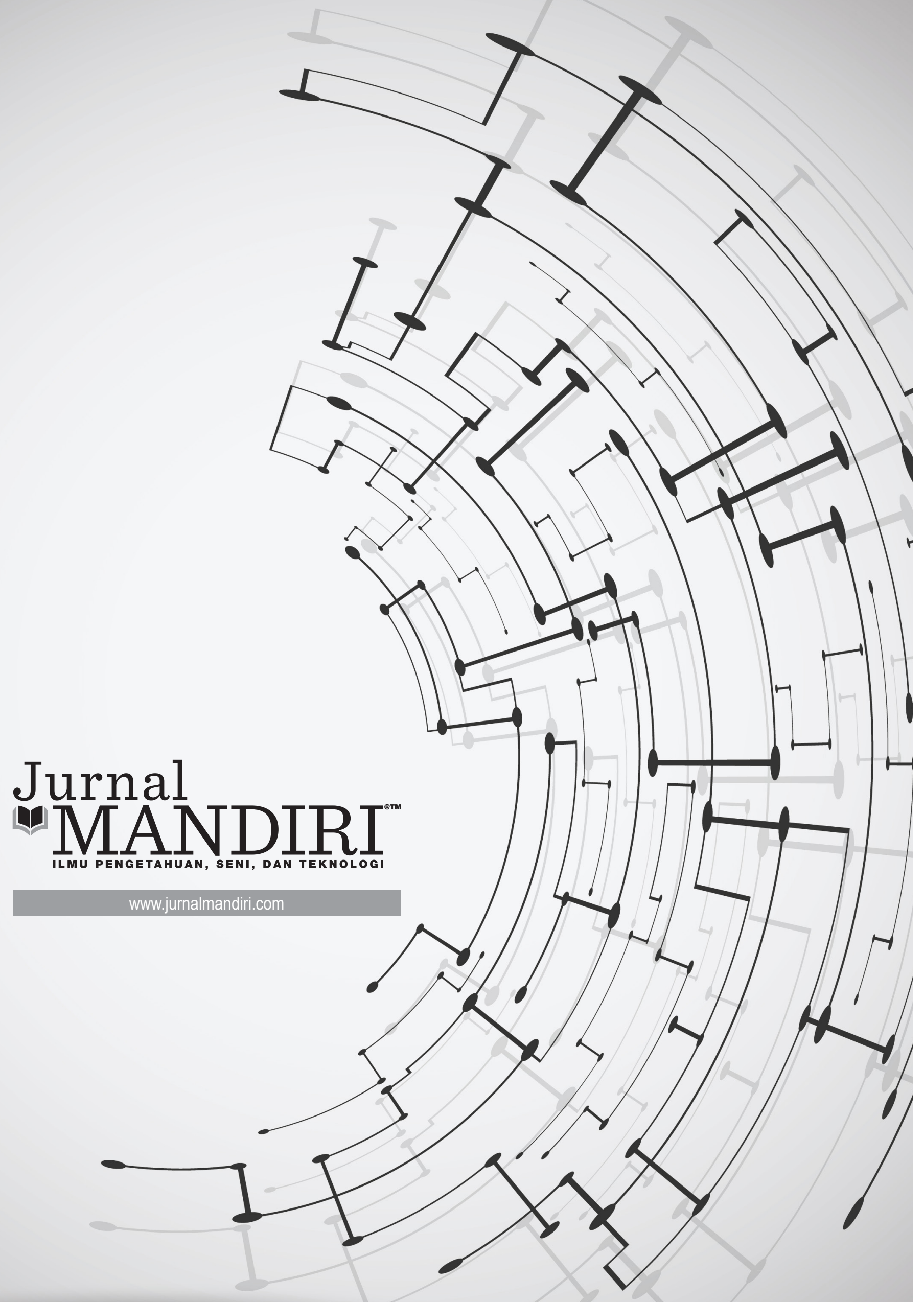


ISSN : 2580-3220, E-ISSN : 2580-4588

J. Mandiri., Vol. 2, No. 2, Desember 2018 (315 - 330)

(C)2018 Lembaga Kajian Demokrasi

dan Pemberdayaan Masyarakat (LKD-PM)

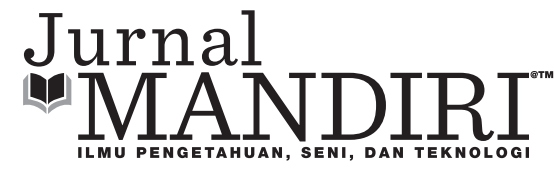

\title{
PENGARUH MOTIVASI DAN DISIPLIN KERJA TERHADAP PRODUKTIFITAS KERJA KARYAWAN PADA PT. DAYA PERKASA
}

\author{
Prasetyo Kurniawan \\ Fakultas Ekonomi, Universitas Pamulang \\ prasetyokurniawan79@gmail.com
}

\begin{abstract}
Abstrak
Penelitian ini bertujuan untuk mengetahui pengaruh motivasi dan disiplin kerja secara parsial maupun secara simultan terhadap produktivitas karyawan pada PT. Daya Perkasa. Metode yang digunakan adalah explanatory research, dan pengujian hipotesis. Dengan teknik survei, menyebar kuesioner dengan skala Likert. Teknik penentuan memakai sampling jenuh dengan 60 responden. Teknik analisis data yang digunakan analisis deskriptif dan analisis statistik inferesial yaitu: 1.Uji Validitas dan Reliabilitas, 2. Analisis Regresi Berganda, 3. Analisis Koefisien Determinasi $\left(R^{2}\right)$, 4. Pengujian Hipotesis dengan Uji Parsial (uji t) dan Uji Simultan (uji F). Hasil Pengujian dan analisisnya adalah sebagai berikut:

1. Terdapat pengaruh positif dan signifikan antara motivasi terhadap produktivitas karyawan, dengan korelasi positif 0,636 dan kontribusi sebesar 43,1\%. Dan nilai $t_{\text {hitung }}$ sebesar 6,628 dengan probability signifikansi t sebesar 0,000.

2. Terdapat pengaruh positif dan signifikan antara disiplin kerja terhadap produktivitas karyawan, dengan korelasi positif 0,638 dan kontribusi sebesar 40,7\%. Dan nilai $t_{\text {hitung }}$ sebesar 6,311 dengan probability signifikansi t sebesar 0,000 .

3. Terdapat pengaruh positif dan signifikan antara motivasi dan disiplin kerja secara simultan terhadap produktivitas karyawan dengan korelasi positif 0,728 dan kontribusi pengaruh sebesar 53,0\% dan sisanya 37,0\% dipengaruhi faktor lain. Uji hipotesis diperoleh $F_{\text {hitung }}$ sebesar 32,194 > 2,770 dengan signifikansi F sebesar 0,000.
\end{abstract}

Kata Kunci : Motivasi, Disiplin Kerja dan Produktivitas Karyawan

\section{PENDAHULUAN \\ Latar Belakang}

Perusahaan merupakan organisasi yang mempunyai berbagai macam tujuan. Aktivitas suatu perusahaan dalam pencapaian tujuan diperlukan pengelolaan sumber daya alam, sumber daya manusia, modal, bahan baku, mesin serta teknologi. Perusahaan harus memperhatikan keterkaitan antara faktor-faktor produksi tersebut, dengan demikian perusahaan dituntut untuk dapat mengelola dengan sebaik-baiknya terutama dalam bidang sum- ber daya manusia sehingga mampu bekerja lebih efektif dan efisien. Suatu organisasi dapat berjalan efektif apabila fungsi-fungsi manajemen seperti perencanaan (planning), pengorganisasian (organizing), pengarahan (actuating) dan pengendalian (controlling) apabila semua itu berfungsi dengan baik, serta memenuhi persyaratan.

Lingkup kompetensi senantiasa berbeda karena pengaruh berbagai Disiplin ilmu mempunyai kepentingan dan cara pandang yang berbeda Sterbler et.ai 1997 dalam Hoffamnn,T 
(1999) menjelaskan dua definisi Kompetensi. Kompetensi dapat dinyatakan sebagai perilaku yang menunjukkan standar kerja minimum menjelaskan 3 lingkup Kompetensi (1) kinerja yang terobservasi (2) standar kualitas atau hasil yang dapat dipenuhi seseorang (3) seseorang yang dapat dicatat (Pengetahuan atau keahlian) dan atau kemampuan yang menunjukkan kinerjanya. Hasibuan (2013) menyampaikan bahwa tujuan tidak mungkin terwujud tanpa peran aktif karyawan meskipun alat-alat yang dimiliki perusahaan begitu canggihnya" Oleh karena itu keberhasilan suatu perusahaan tidak hanya tergantung dengan teknologi perusahaan saja namun juga tergantung pada aspek sumber daya manusia yang dimiliki oleh perusahaan.

Dalam meningkatkan produktivitas kerja karyawan karyawan yaitu dalam pemberian motivasi. Motivasi penting diberikan kepada karyawan karena akan membangkitkan semangat untuk bekerja dan menghasilkan produktivitas kerja karyawan yang tinggi. Motivasi dapat diartikan sebagai kekuatan baik yang berasal dari dalam diri maupun dari luar diri seseorang yang mendorong berperilaku kerja sesuai dengan ketentuan, intensitas dan jangka waktu tertentu yang berhubungan dengan motivasi intrinsik dan ekstrinsik dalam melaksanakan pekerjaan. Pentingnya motivasi kerja bagi suatu perusahaan yakni sebagai faktor pendorong karyawan.

Menurut David McCleland dalam Miftah Toha (2012:235) mengemukakan "Motivasi merupakan seperangkat kekuatan baik yang berasal dari dalam diri maupun dari luar diri seseorang yang mendorong untuk memulai berperilaku kerja sesuai dengan format, arah, intensitas dan jangka waktu tertentu". Organisasi juga dituntut mampu mengidentifikasikan kemauan para anggotanya yang menimbulkan kepuasan kerja melalui berbagai cara dengan memenuhi kebutuhan anggota organisasi, baik yang bersifat motivator sebagai faktor intrinsik maupun hygiene sebagai faktor ekstrinsik.

Faktor disiplin kerja sangat berperan penting dalam pelaksanaan kerja karyawan. Karena menurut Hasibuan (2013:193) adalah kesadaran dan kesediaan menaati semua peraturan perusahaan dan norma-norma sosial yang berlaku. Sedangkan menurut pendapat ahli yang lain, Rivai (2013:444) mengatakan bahwa disiplin kerja adalah suatu alat yang digunakan para manager untuk berkomunikasi dengan karyawan agar mereka bersedia untuk mengubah suatu perilaku, serta sebagai upaya meningkatkan kesadaran dan kesediaan seseorang mentaati semua peraturan perusahaan dan norma-norma sosial yang berlaku. Pada akhirnya pegawai yang mempunyai kedisiplinan kerja yang tinggi akan mempunyai kinerja yang baik karena waktu kerja dimanfaatkan sebaik mungkin untuk melaksankan pekerjaan sesuai dengan target yang ditetapkan. Karyawan wajib mendisiplinkan diri masing-masing mulai dari lingkungan yang paling kecil yaitu keluarga sampai lingkungan kerja agar tercipta produktivitas kerja karyawan yang baik dalam menjalani tugasnya sebagai karyawan.

PT. Daya Perkasa merupakan salah satu perusahaan industri tekstil yang dikenal sebagai penjahit/garment, dalam mengatasi persaingan yang semakin ketat di industri garment, PT. Daya Perkasa menyadari pentingnya memiliki sumber daya manusia yang berkualitas dan memiliki komitmen serta menjaga kualitas yang konsisten untuk mampu mendorong kinerja organisasi atau perusahaan yang kian lama membutuhkan daya dukung yang kuat dalam usaha mencapai misi dan misinya. Oleh sebab itu perusahaan sangat mengharapkan setiap karyawannya dapat menciptakan disiplin kerja yang tinggi demi kemajuan perusahaan dan pencapaian tujuan perusahaan yang efektif dan efisien. Akan tetapi hal ini tidak mudah apabila disiplin kerja karyawan masih rendah.

Salah satu tantangan yang dihadapi dalam meningkatkan produktivitas kerja karyawan kerja karyawan adalah rendahnya tingkat kesadaran karyawan terhadap tugas dan tanggung jawab mereka dalam melaksanakan pekerjaan. Rendahnya kesadaran karyawan terhadap tugas dan tanggung jawabnya tercermin dalam berbagai hal, seperti karyawan yang tidak taat terhadap jam kerja serta karyawan yang tidak bersungguh-sungguh dalam melaksanakan tugas dan tanggung jawabnya dalam melaksanakan pekerjaan. Disiplin kerja yang baik adalah bukan atas dasar paksaan atau karena adanya punishment (peringatan) maupun reward (penghargaan) yang diberikan, akan tetapi berdasarkan kesadaran dari dalam diri karyawan masing-masing. Seperti yang terjadi pada karyawan di PT. Daya Perkasa, berdasarkan hasil penelitian awal terlihat masih 
kurangnya disiplin kerja karyawan yang dilakukan baik oleh karyawan dinas dalam maupun karyawan dinas luar. Diantaranya banyak karyawan yang terlambat hadir dari jam kerja yang ditentukan dan karyawan yang tidak hadir tanpa memberikan keterangan. Persoalan-persoalan seperti ini mencerminkan tinggi rendahnya tingkat kedisiplinan kerja karyawan, sehingga akan turut menurunkan tingkat pretasi kerja karyawan.

Pencapaian keunggulan bersaing telah mengarahkemunculnyabidangyangdikenalsebagai sumber daya manusia untuk meningkatkan kinerja bisnis dan mengembangkan kultur organisasi yang mendorong inovasi dan peran penting atau implementasi yang berhasil dari sebuah rencana. Suatu kebutuhan yang tidak terpuaskan akan menciptakan ketegangan yang merangsang dorongan dalam diri individu untuk berperilaku dalam menemukan tujuan tertentu. Oleh karena itu, motivasi sangat penting karena menyangkut kebutuhan individu yang harus sesuai dengan tujuan organisasi.

Keberhasilan organisasi juga ditentukan oleh tanggung jawab karyawan dalam melaksanakan tugasnya secara tepat waktu pada saat masuk jam kantor, sedangkan dalam observasi yang telah dilakukan masih banyak karyawan yang menunda pelaksanaan tugas kantor, terlambat saat masuk jam kerja, keluar kantor pada saat jam-jam kerja dan kurangnya komunikasi antar karyawan dengan pimpinan mempengaruhi produktivitas kerja karyawan pada masing-masing individu, karena produktivitas kerja karyawan sendiri dipengaruhi oleh karakteristik individu dan faktor lingkungan perusahaan, baik suasan kerja lingkungan fisik maupun leadership dari pimpinan. Sedangkan para atasan sebagai motivator bagi para karyawan berusaha agar produktivitas kerja karyawan terus meningkat, perusahaan juga memberikan reward (bonus) yang sesuai dengan produktivitas kerja karyawan yang diberikan karayawan pada perusahaan. Produktivitas kerja karyawan suatu keberhasilan individu dalam mengerjakan tugasnya yang bisa dilihat dari segi dimensi keterikatan, keahlian merencanakan, daya usaha dalam pekerjaan dan produktivitas kerja karyawan secara keseluruhan.

Berdasarkan latar belakang permasalahan diatas, maka penulis tertarik untuk melakukan penelitian lebih lanjut dengan judul: "Pengaruh Motivasi dan Disiplin Kerja Terhadap Produktivitas Kerja Karyawan Pada PT. Daya Perkasa"

\section{Pembatasan Masalah}

Dengan keterbatasan peneliti serta agar lebih mudah dipahami dan dimengerti maka penelitian ini penulis memberikan batasanbatasan yang diteliti, yaitu mengenai pengaruh antara motivasi dan disiplin kerja terhadap produktivitas karyawan pada PT. Daya Perkasa, dengan cara melakukan penyebaran kuesioner kepada karyawan.

\section{Perumusan Masalah}

Berdasarkan identifikasi dan pembatasan masalah di atas, maka untuk mencegah terjadinya kerancuan dalam pembahasan, perlu penulis berikan suatu perumusan masalah sebagai berikut :

1. Apakah terdapat pengaruh secara parsial antara motivasi kerja terhadap produktivitas karyawan pada PT. Daya Perkasa.

2. Apakah terdapat pengaruh secara parsial antara disiplin kerja terhadap produktivitas karyawan pada PT. Daya Perkasa.

3. Apakah terdapat pengaruh antara motivasi dan disiplin kerja secara bersama-sama terhadap produktivitas karyawan pada PT. Daya Perkasa.

\section{Tujuan Penelitian}

Tujuan penelitian ini adalah :

1. Untuk mengetahui seberapa besar pengaruh secara parsial antara disiplin kerja terhadap produktivitas karyawan pada PT. Daya Perkasa.

2. Untuk mengetahui seberapa besar pengaruh secara parsial antara motivasi terhadap produktivitas karyawan pada PT. Daya Perkasa.

3. Untuk mengetahui seberapa besar pengaruh secara simultan antara disiplin kerja dan motivasi terhadap produktivitas karyawan pada PT. Daya Perkasa.

\section{Tinjauan Teoritik}

\section{Motivasi}

Menurut Sarwoto (2011) secara konkrit motivasi dapat diberi batasan sebagai "Proses pemberian motif (penggerak) bekerja kepada 
para bawahan sedemikian rupa sehingga mereka mau bekerja dengan ikhlas demi tercapainya tujuan organisasi secara efisien. Maka Pengertian motivasi adalah pemberian atau penimbulan motif atau dapat pula diartikan sebagai hal atau keadaan menjadi motif, dan sesuatu yang menimbulkan semangat atau dorongan kerja. Sedangkan Menurut Hasibuan (2016:141) motivasi berasal dari kata latin "Movere" yang artinya dorongan atau mengarahkan. Motivasi ditunjukan pada sumber daya manusia umumnya dan bawahan khususnya. Motivasi mempersoalkan bagaimana caranya mengarahkan daya potensi bawahan, agar mau bekerja sama secara produktif, berhasil mencapai dan mewujudkan tujuan yang telah ditentukan.

Menurut Maslow dalam Sutrisno (2014:55), menyatakan bahwa motivasi adalah pemberian daya penggerak yang menciptakan kegairahan kerja seseorang, agar mereka mau bekerja sama, bekerja efektif dan terintegrasi dengan segala upayanya untuk mencapai kepuasan dalam bekerja. Motivasi kerja karyawan dipengaruhi oleh banyak kebutuhan yang kemudian dari faktor kebutuhan tersebut diturunkan menjadi indikator-indikator untuk mengetahui motivasi kerja karyawan, yang diuraikan sebagai berikut:

a. Kebutuhan fisiologis (physiological need) yaitu Kebutuhan fisiologis Kebutuhan fisiologis merupakan hirarki kebutuhan manusia yang paling dasar yang merupakan kebutuhan untuk dapat hidup seperti makan, minum, perumahan, oksigen, tidur dan sebagainya.

b. Kebutuhan rasa aman (safety need). Yaitu Kebutuhan akan rasa aman ini meliputi keamanan akan perlindungan dari bahaya kecelakaan kerja, jaminan akan kelangsungan pekerjaannya dan jaminan akan hari tuanya pada saat mereka tidak lagi bekerja.

c. Kebutuhan sosial (Social need). Yaitu kebutuhan untuk persahabatan, afiliasi dana interaksi yang lebih erat dengan orang lain. Dalam organisasi akan berkaitan dengan kebutuhan akan adanya kelompok kerja yang kompak, supervisi yang baik, rekreasi bersama.

d. Kebutuhan penghargaan (esteem need) yaitu : Kebutuhan ini meliputi kebutuhan keinginan untuk dihormati, dihargai atas prestasi seseorang, pengakuan atas kemampuan dan keahlian seseorang serta efektivitas kerja seseorang.

e. Kebutuhan aktualisasi diri (self actualization need). Yaitu Kebutuhan untuk menunjukkan kemampuan dan potensi yang dimiliki seseorang. Kebutuhan akan aktualisasi diri ada kecenderungan potensinya meningkat karena orang mengaktualisasikan perilakunya.

\section{Disiplin kerja}

Menurut Setiyawan dan Waridin (2012) "Disiplin merupakan suatu bentuk ketaatan terhadap aturan, baik tertulis maupun tidak tertulis yang telah ditetapkan". Disiplin kerja pada dasarnya selalu diharapkan menjadi ciri setiap sumber daya manusia dalam organisasi, karena dengan kedisplin akan berjalan dengan baik dan bisa mencapai tujuannya dengan baik pula.

Menurut Hasibuan (2016) "Kedisiplinan adalah kesadaran dan kesediaan seseorang menaati semua peraturan dan peraturan-peraturan yang berlaku". Disiplin yang baik dapat mencerminkan seberapa besar tanggung jawab karyawan terhadap pekerjaannya. Hal ini dapat mendorong gairah kerja sehingga tujuan organisasi dapat tercapai. Lebih lanjut Menurut Hasibuan (2016), indikator yang mempengaruhi tingkat kedisiplinan seseorang dalam suatu organisasi, diantaranya :

a. Tujuan dan kemampuan adalah tujuan (pekerjaan) yang dibebankan kepada karyawan yang harus sesuai dengan pegawai yang bersangkutan.

b. Keteladanan pemimpin yaitu pimpinan yang dijadikan teladan dan panutan oleh bawahannya.

c. Balas jasa adalah pemberian balas jasa yang dibayarkan oleh pegawai berdasarkan pekerjaan yang telah diselesaikan.

d. Sanksi hukuman hendaknya bersifat mendidik dan menjadi alat motivasi untuk memeilhara kedisiplinan dalam perusahaan.

e. Ketegasan adalah pimpinan menegur dan menghukum setiap karyawan yang melanggar.

\section{Produktivitas Karyawan}

Menurut Sutrisno (2013) produkivitas adalah hubungan antara keluaran (barang-ba- 
rang atau jasa) dengan masukan (tenaga kerja, bahan, uang). Produktivitas merupakan ukuran efisiensi produktif. Sedangkan menurut Sedarmayanti (2013) filosopi dan spirit tentang produktivitas sudah ada sejak awal peradaban manusia karena makna produktivitas adalah keinginan (the will) dan upaya (effort) manusia untuk meningkatkan kualitas kehidupan dan penghidupan disegala bidang.

Menurut Sedarmayanti (2013) : Produktivitas kerja menunjukkan bahwa individu merupakan perbandingan dari efektivitas keluaran (pencapaian untuk kerja maksimal) dengan efisiensi salah satu masukan (tenaga kerja) yang mencakup kuantitas, kualitas, dalam waktu tertentu". Produktivitas kerja adalah suatu ukuran dari pada hasil kerja atau kinerja seseorang dengan proses input sebagai masukan dan output sebagai keluarannya yang merupakan indikator dari pada kinerja karyawan dalam menentukan bagaimana usaha untuk mencapai produktivitas yang tinggi dalam suatu organisasi. Lebih lanjut disampaikan bahwa indikator produktivitas menurut Sedarmayanti (2013) meliputi:

a. Tindakan konstruktif. Yaitu sesuatu yang bersifat membangun, membina, dan memperbaiki.

b. Percaya pada diri sendiri. kemampuan dan penilaian (judgement) diri sendiri dalam melakukan tugas dan memilih pendekatan yang efektif. Hal ini termasuk kepercayaan atas kemampuan dan keputusannya.

c. Bertanggung jawab. Yaitu kesadaran manusia akan tingkah laku atau perbuatannya yang di sengaja maupun yang tidak di sengaja. Tanggung jawab juga berarti berbuat sebagai perwujudan kesadaran akan kewajiban.

d. Mampu mengatasi persoalan dan dapat menyesuaikan diri dengan lingkungan yang berubah-ubah. Mudah beradaptasi yang akan memperkuat persaingan yang terus meningkat dalam suatu perusahaan sehingga dapat pengatasi masalah dengan bijaksana.

e. Mempunyai peran positif terhadap lingkungannya, imaginative, dan inovatif). yaitu dengan sudah mempunyai visi misi yang kuat, maka dapat memberikan konribusi positif kepada perusahaan.

\section{Hipotesis Penelitian}

Hipotesis menurut Sugiyono (2016) adalah jawaban sementara terhadap rumusan masalah. Karena sifatnya masih sementara, maka perlu dibuktikan kebenarannya melalui data empirik yang terkumpul.

Adapun Hipotesis yang penulis ajukan adalah sebagai berikut:

$\mathrm{H}_{1}$ : Diduga terdapat pengaruh positif dan signifikan antara motivasi terhadap produktivitas karyawan pada PT. Daya Perkasa.

$\mathrm{H}_{2}$ : Diduga terdapat pengaruh positif dan signifikan antara disiplin kerja terhadap produktivitas karyawan pada PT. Daya Perkasa.

$\mathrm{H}_{3}$ : Diduga terdapat pengaruh positif dan signifikan antara motivasi dan disiplin kerja secara bersama-sama terhadap produktivitas karyawan pada PT. Daya Perkasa.

\section{METODOLOGI PENELITIAN \\ Tempat dan Waktu Penelitian}

Penulis mengadakan penelitian pada PT. Daya Perkasa di Jalan Raya Gatot Subroto Kav.22 Jakarta Selatan.

\section{POPULASI DAN SAMPEL Populasi}

Populasi penelitian merupakan sekumpulan objek yang ditentukan melalui suatu kriteria tertentu yang akan dikategorikan ke dalam objek yang akan diteliti. Menurut Sugiyono (2016) mendefinisikan "Populasi adalah jumlah wilayah generalisasi yang terdiri atas obyek atau subyek yang mempunyai kualitas dan karakteristik yang ditetapkan oleh peneliti dan kemudian ditarik kesimpulannya. Adapun populasi dalam penelitian ini adalah karyawan PT. Daya Perkasa.

\section{Sampel}

Menurut Sugiyono (2016) yaitu "Sampel adalah jumlah dan karakteristik yang dimiliki oleh populasi tersebut". Sedangkan menurut Suharsini Arikunto (2010), berpendapat bahwa "Sampel adalah sebagian atau wakil populasi yang diteliti".Dalam pengambilan sampel dapat menggunakan sampling jenuh dimana menurut 
Sugiyono (2016) berpendapat "Sampling jenuh adalah teknik penentuan sampel bila semua anggota populasi digunakan sebagai sampel". Istilah lain sampel jenuh adalah sensus, dimana anggota populasi di jadikan sebagai sampel. Dengan demikian sampel dalam penelitian ini adalah teknik sampling jenuh yaitu orang karyawan PT. Daya Perkasa, dalam hal ini berjumlah 60 orang.

\section{Variabel Penelitian}

Dalam penelitian ini terdapat tiga variabel, yaitu variabel independen dan variabel dependen, sebagai berikut :

1. Variabel bebas (independent variable) Variabel bebas yang dalam hubungannya dengan variabel lain bertindak sebagai penyebab atau yang mempengaruhi variabel dependen. Pada penelitian ini sebagai variabel independen yakni motivasi dan disiplin kerja. Variabel independen sering disebut sebagai predictor yang dilambangkan dengan $\mathrm{X}$.

2. Variabel terikat (dependent variable) Variabel yang tergantung dengan variabel lain, atau variabel yang dapat dipengaruhi oleh variabel lain. Sering disebut variabel respon di mana dalam penelitian ini adalah produktivitas karyawan yang dilambangkan dengan $\mathrm{Y}$.

\section{Definisi Operasional Variabel}

Pengertian operasional variabel ini kemudian diuraikan menjadi indikator empiris yang meliputi :

1. Motivasi $\left(\mathrm{X}_{1}\right)$

Yang dimaksud motivasi dalam penelitian ini pemberian daya penggerak yang menciptakan kegairahan kerja seseorang, agar mereka mau bekerja sama, bekerja efektif dan terintegrasi dengan segala upaya untuk mencapai kepuasan dalam bekerja. Maslow dalam Sutrisno (2014). Adapun indikator yang digunakan meliputi: Kebutuhan fisiologis, kebutuhan rasa aman, kebutuhan sosial, kebutuhan penghargaan dan kebutuhan aktualisasi diri.

\section{Disiplin Kerja $\left(\mathrm{X}_{2}\right)$}

Yang dimaksud disiplin kerja merupakan kesadaran dan kesediaan seseorang menaati semua peraturan dan peraturan- peraturan yang berlaku Menurut Hasibuan (2016). Adapun indikator yang digunakan meliputi: tujuan dan kemampuan karyawan, keteladanan dari pimpinan, pemberian balas jasa, pemberian sanksi dan hukuman serta ketegasan dalam menegakkan peraturan

3. Produktivitas Karyawan (Y)

Merupakan suatu ukuran dari pada hasil kerja atau kinerja seseorang dengan proses input sebagai masukan dan output sebagai keluarannya yang merupakan indikator dari pada kinerja karyawan dalam menentukan bagaimana usaha untuk mencapai produktivitas kerja karyawan yang tinggi dalam suatu organisasi. (Sedarmayanti, 2013). Adapun indikator yang digunakan meliputi: Tindakan konstruktif, Percaya pada diri sendiri, Bertanggung jawab, Mampu mengatasi masalah, Mempunyai kontribusi positif pada perusahaan.

\section{Metode Pengumpulan Data}

\section{Kuesioner}

Dalam penelitian ini untuk mendapatkan data primer kuantitatif, penulis menghubungi responden yaitu karyawan PT. Daya Perkasa.

\section{Studi Pustaka}

Untuk medapatkan data sekunder penulis melakukan dengan cara penelaahan terhadap literatur-literatur berupa buku-buku kuliah dan data yang diperoleh dalam bentuk yang sudah jadi, sudah diolah oleh pihak lain biasanya dalam bentuk publikasi serta bahan-bahan yang berhubungan dengan masalah yang berkaitan dengan penelitian ini.

\section{Metode Analisis Data}

Metode analisis data yang digunakan dalam penelitan ini adalah:

\section{Uji Validitas}

Valid adalah menunjukkan derajat ketepatan antara data yang sesungguhnya terjadi pada obyek dengan data yang dapat dikumpulkan oleh peneliti. Menurut Sugiyono (2016) "Valid berarti terdapat kesamaan antara data yang terkumpul dengan data yang sesungguhnya". Kriteria atau syarat keputusan suatu instrumen dikatakan valid dan tidaknya menurut Ghozali (2014:52) yaitu dengan membandingkan antara Chronbatch Alpha dengan 
0,30 dengan ketentuan :
a. Jika Chronbatch Alpha > 0,30, maka instrumen valid,
b. Jika chronbatch Alpha < 0,30, maka instrumen tidak valid.

\section{Uji Reliabilitas}

Uji reliabilitas merupakan serangkaian pengukuran atau serangkaian alat ukur yang memiliki konsistensi bila pengukuran yang dilakukan dengan alat ukur itu dilakukan secara berulang. Instrumen yang baik tidak akan bersifat tendensius mengarahkan responden untuk memilih jawaban tertentu.

Kriteria yang digunakan apabila suatu alat ukur memberikan hasil yang stabil, maka disebut alat ukur itu handal. Pengukuran dilakukan sekali dan reliabilitas dengan uji statistik Cronbach Alpha ( $\alpha$ ). Dalam pengukurannya one shot akan dilakukan dengan analisis Cronbach's Alpha. Ghozali (2014:238) mengklasifikasikan nilai Cronbach's Alpha sebagai berikut:

a. Nilai Cronbach's Alpha antara 0,00-0,20 dikatakan kurang reliabel;

b. Nilai Cronbach's Alpha antara 0,21 - 0,40 dikatakan agak reliabel;

c. Nilai Cronbach's Alpha antara 0,41 - 0,60 dikatakan cukup reliabel;

d. Nilai Cronbach's Alpha antara 0,61 - 0,80 dikategorikan reliabel;

e. Nilai Cronbach's Alpha antara 0,81-1,00 dikatakan sangat reliabel.

\section{Analisis Regresi Berganda}

Di mana untuk mencapai tujuan penelitian yaitu menganalisis pengaruh motivasi $\left(\mathrm{X}_{1}\right)$ dan disiplin kerja $\left(\mathrm{X}_{2}\right)$ secara bersama-sama terhadap produktivitas karyawan $(\mathrm{Y})$ adalah dengan menggunakan analisis regresi berganda (Multiple regresional analisis).

\section{Analisis Koefisien Determinasi}

Dalam penelitian ini untuk mengetahui berapa besar prosentase kontribusi dari variabel disiplin kerja dan motivasi terhadap produktivitas karyawan pada PT. Daya Perkasa baik secara parsial maupun secara simultan.

\section{Uji Hipotesis}

Pengujian hipotesis dimaksudkan untuk menguji dugaan sementara yang dirumuskan dalam hipotesis berdasarkan data empiris.
Dalam penelitian ini pengujian hipotesis dilakukan dengan uji $t$ dan uji $F$.

a. Uji t

Uji t digunakan untuk menguji signifikansi variasi hubungan antar variabel $\mathrm{X}$ dan Y. Dalam penelitian ini untuk menguji apakah variabel motivasi $\left(\mathrm{X}_{1}\right)$ dan disiplin kerja $\left(\mathrm{X}_{2}\right)$ secara parsial benar-benar berpengaruh secara parsial terhadap variabel dependen.

b. Uji F

Pengujian hipotesis simultan (Uji F) bertujuan untuk mengetahui pengaruh secara bersama-sama variabel independen terhadap variabel dependen. Dalam penelitian ini untuk menguji apakah variabel motivasi $\left(\mathrm{X}_{1}\right)$ dan disiplin kerja $\left(\mathrm{X}_{2}\right)$ secara bersama-sama benar-benar berpengaruh secara parsial terhadap variabel dependen.

\section{ANALISIS DAN PEMBAHASAN \\ Analisis Deskriptif Variabel Penelitian}

Analisis deskriptif yaitu untuk memberikan gambaran mengenai hasil penelitian secara umum, bagaimana karakteristik subyek penelitian sehubungan dengan variabel-variabel yang diteliti. Sebelum dilakukan analisis statistik terlebih dahulu dilakukan pembobotan terhadap skor masing-masing variabel. Metode yang diambil dalam penelitian ini adalah metode pengukuran Likert. Dimana pertanyaan mengandung lima alternatif jawaban. Dan bentuk pertanyaan telah disusun menggunakan pengukuran Likert yang diberi bobot sebagai berikut:

\begin{tabular}{|c|c|}
\hline \multicolumn{2}{|c|}{ TABEL 1. SKALA LIKERT } \\
\hline JAWABAN & BOBOT \\
\hline Sangat Setuju (SS) & 5 \\
\hline Setuju (S) & 4 \\
\hline Kurang Setuju (KS) & 3 \\
\hline Tidak Setuju (TS) & 2 \\
\hline Sangat Tidak Setuju (STS) & 1 \\
\hline & Sumber: Sugivono (2016) \\
\hline$P=\frac{}{\text { RANGE }}$ \\
KELAS
\end{tabular}

Maka dapat ditetapkan interval sebagai berikut : 


\begin{tabular}{|c|c|}
\hline \multicolumn{2}{|c|}{ TABEL 2. RENTANG SKALA } \\
\hline NILAI RATA-RATA & BOBOT \\
\hline $1,00-1,79$ & Sangat Tidak Setuju (STS) \\
\hline $1,80-2,59$ & Tidak Setuju (TS) \\
\hline $2,60-3,39$ & Kurang Setuju (KS) \\
\hline $3,40-4,19$ & Setuju (S) \\
\hline $4,20-5,00$ & Sangat Setuju (SS) \\
\hline & Sumber: Sugiyono (2016) \\
\hline
\end{tabular}

\section{Variabel Motivasi $\left(\mathrm{X}_{1}\right)$}

Kriteria obyek yang diteliti berdasarkan pada tanggapan responden pada butir pertanyaan variabel motivasi $\left(\mathrm{X}_{1}\right)$ yang diberikan sebagi berikut:

\begin{tabular}{|c|c|c|c|c|c|c|c|c|}
\hline \multicolumn{9}{|c|}{ TABEL 3. VARIABEL MOTIVASI $\left(X_{1}\right)$} \\
\hline \multirow{2}{*}{ No } & \multirow{2}{*}{ Pernyataan } & \multicolumn{5}{|c|}{ Kriteria Jawaban } & \multirow{2}{*}{ Jumlah } & \multirow{2}{*}{ Skor } \\
\hline & & STS & TS & KS & s & sS & & \\
\hline 1 & Mencari upah yang sesuai & 0 & 2 & 18 & 27 & 13 & 60 & 3.85 \\
\hline 2 & Menyisihkan penghasilan & 0 & 2 & 18 & 30 & 10 & 60 & 3.80 \\
\hline 3 & Jaminan kesehatan & 0 & 2 & 17 & 33 & 8 & 60 & 3.78 \\
\hline 4 & Jaminan untuk hari tua & 0 & 3 & 16 & 25 & 16 & 60 & 3.90 \\
\hline 5 & Pendapat dari atasan & 0 & 1 & 16 & 31 & 12 & 60 & 3.90 \\
\hline 6 & Dorongan kreativitas & 0 & 1 & 17 & 31 & 11 & 60 & 3.87 \\
\hline 7 & Apresiasi dari pimpinan & 0 & 2 & 12 & 33 & 13 & 60 & 3.95 \\
\hline 8 & Penyelesaian tugas & 0 & 1 & 17 & 29 & 13 & 60 & 3.90 \\
\hline 9 & Tugas \& tujuan organisasi & 0 & 1 & 19 & 27 & 13 & 60 & 3.87 \\
\hline 10 & Pengembangan potensi & 0 & 1 & 10 & 29 & 20 & 60 & 4.13 \\
\hline & Jumlah & 0 & 16 & 160 & 295 & 129 & 600 & AVG \\
\hline & Persentase (\%) & $0.0 \%$ & $2.7 \%$ & $26.7 \%$ & $49.2 \%$ & $21.5 \%$ & $100 \%$ & 3.90 \\
\hline & & & & & & & Sumber: Da & mer dio \\
\hline
\end{tabular}

Berdasarkan data pada tabel di atas, tanggapan responden atas pernyataan pada variabel motivasi diperoleh rata-rata skor 3.90 termasuk pada rentang skala 3,40-4,19 dengan kriteria baik, namun masih ada sejumlah responden yang menjawab kurang setuju dan tidak setuju mencapai $35,14 \%$.

\section{Variabel Disiplin Kerja $\left(\mathbf{X}_{2}\right)$}

Kriteria obyek yang diteliti berdasarkan pada tanggapan responden pada butir pertanyaan variabel disiplin kerja $\left(\mathrm{X}_{2}\right)$ yang diberikan sebagai berikut:

\begin{tabular}{|c|c|c|c|c|c|c|c|c|}
\hline \multicolumn{9}{|c|}{ TABEL 4. VARIABEL DISIPLIN KERJA $\left(X_{2}\right)$} \\
\hline \multirow[b]{2}{*}{ No } & \multirow[b]{2}{*}{ Pernyataan } & \multicolumn{5}{|c|}{ Kriteria Jawaban } & \multirow{2}{*}{ Jumlah } & \multirow[b]{2}{*}{ Skor } \\
\hline & & STS & TS & KS & $\mathbf{s}$ & SS & & \\
\hline 1 & Tujuan organisasi & 0 & 1 & 17 & 32 & 10 & 60 & 3.85 \\
\hline 2 & Pemberian tugas sesuai & 0 & 2 & 19 & 33 & 6 & 60 & 3.72 \\
\hline 3 & Pimpinan memberi contoh & 0 & 1 & 22 & 24 & 13 & 60 & 3.82 \\
\hline 4 & Bekerja yang produktif & 0 & 2 & 16 & 27 & 15 & 60 & 3.92 \\
\hline 5 & Pemberian balas jasa & 0 & 2 & 26 & 22 & 10 & 60 & 3.67 \\
\hline 6 & Ketentuan upah, gaji & 0 & 0 & 15 & 34 & 11 & 60 & 3.93 \\
\hline 7 & Pemberian sanksi, aturan & 0 & 0 & 23 & 25 & 12 & 60 & 3.82 \\
\hline 8 & Hukuman yang baik & 0 & 0 & 24 & 25 & 11 & 60 & 3.78 \\
\hline 9 & Sanksi yang tegas & 0 & 1 & 19 & 29 & 11 & 60 & 3.83 \\
\hline 10 & Sanksi tidak pilih kasih & 0 & 0 & 11 & 24 & 25 & 60 & 4.23 \\
\hline & Jumlah & 0 & 9 & 192 & 275 & 124 & 600 & AVG \\
\hline & Persentase (\%) & $0.0 \%$ & $1.5 \%$ & $32.0 \%$ & $45.8 \%$ & $20.7 \%$ & $100 \%$ & 3.86 \\
\hline & & & & & & & Sumber: Dat & ner diol \\
\hline
\end{tabular}


Berdasarkan data tabel di atas, tanggapan responden pada variabel disiplin kerja diperoleh rata-rata skor 3.86 termasuk pada rentang skala 3,40-4,19 dengan kriteria baik, namun masih ada sejumlah responden yang menjawab kurang setuju dan tidak setuju mencapai $35,14 \%$.
3. Variabel Produktivitas Karyawan (Y)

Kriteria obyek yang diteliti berdasarkan pada tanggapan responden pada butir pertanyaan variabel produktivitas kerja karyawan $(\mathrm{Y})$ yang diberikan sebagi berikut:

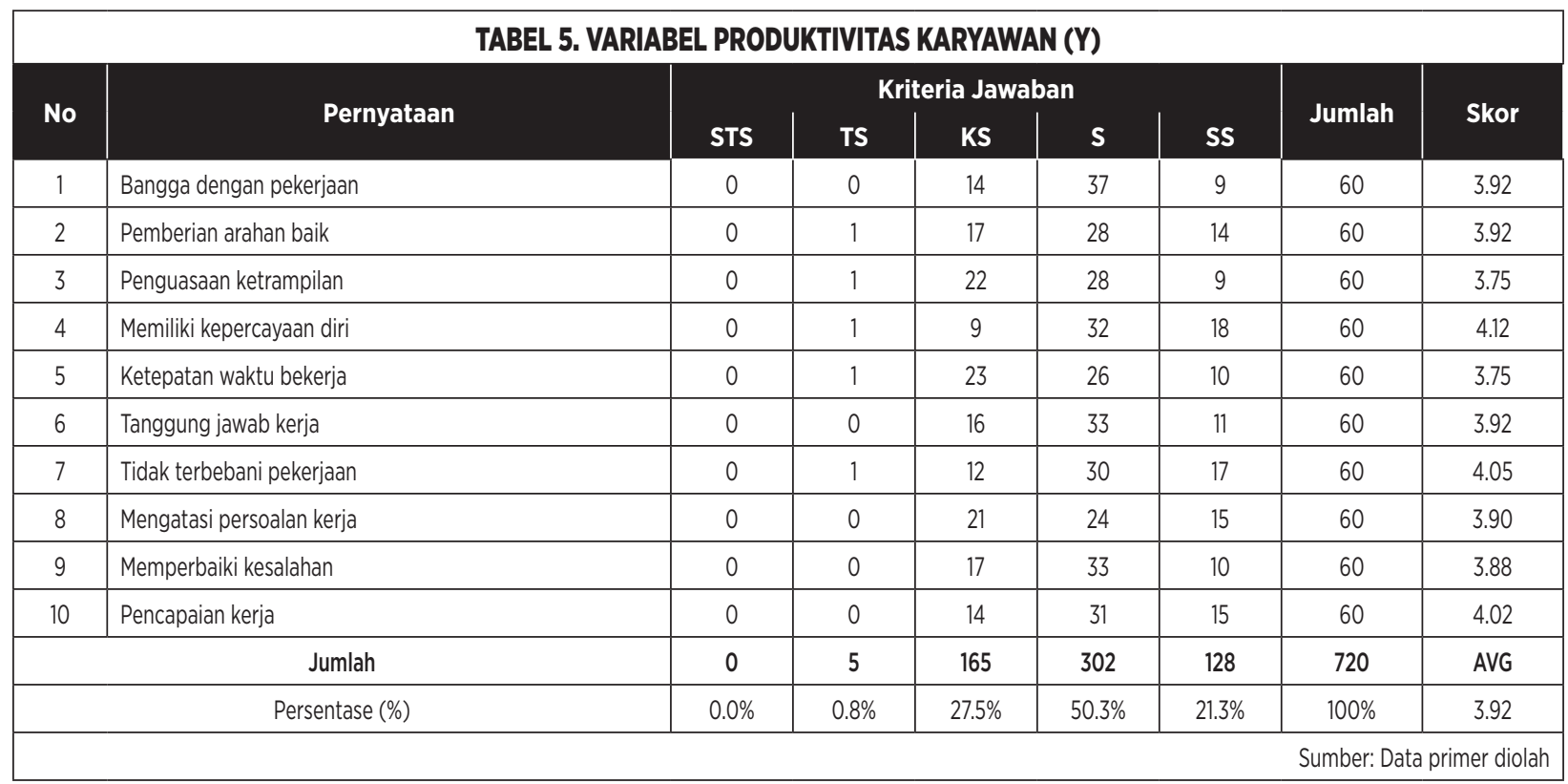

Berdasarkan tabel di atas, tanggapan responden variabel produktiivitas karyawan beragam, diperoleh rata-rata skor sebesar 3.92 termasuk pada rentang skala 3,40-4,19 dengan kriteria baik, namun masih ada sejumlah responden yang menjawab kurang setuju dan tidak setuju mencapai 35,14\%.

\section{Pengujian Instrumen Data}

\section{Hasil Uji Validitas}

Berdasar perhitungan dengan menggunakan menggunakan Software IBM SPSS (Statistical Program for Social Science) versi 24. Seluruh butir pernyataan yang digunakan dalam penelitian diperoleh nilai chronbatch alpha > titik kritis alpha 0,30, dengan demikian maka semua butir pernyataan dikatakan valid.

\section{Hasil Uji Reliabilitas}

Berdasar perhitungan dengan menggunakan menggunakan Software IBM SPSS (Statistical Program for Social Science) versi 24. Seluruh butir pernyataan yang digunakan dalam penelitian diperoleh nilai chronbatch alpha > titik kritis alpha 0,60 , dengan demikian maka semua butir pernyataan dikatakan reliabel dan data layak untuk diolah ke pengujian beri- kutnya.

\section{Pengujian Asimsi Klasik}

\section{Uji Normalitas}

Uji Normalitas dalam penelitian ini menggunakan Kolmogorov-Smirnov Test dengan syarat significancy $\alpha>0.050$. Hasil uji normalitas dengan Kolmogorov-Smirnov sebagai berikut :

\begin{tabular}{|l|r|r|r|r|r|r|}
\hline \multicolumn{6}{|c|}{ TABEL 6. HASIL UJI NORMALITAS DENGAN } \\
KOLMOGOROV-SMIRNOV TEST \\
\hline \\
\hline
\end{tabular}

Berdasarkan hasil pengujian pada tabel di atas, diperoleh nilai signifikansi $\alpha=0,080$ dimana nilai tersebut lebih besar dari nilai $\alpha=$ 0,050 atau $(0,080>0,050)$. Dengan demikian maka asumsi distribusi persamaan pada uji ini adalah normal.

\section{Uji Multikolinieritas}

Uji Multikolonieritas dalam penelitian ini menggunakan Colinierity Statistics Test dengan 
syarat sebagai berikut :

a. Jika nilai VIF $>10$ dan nilai tolerance value $>1$ maka terjadi gejala multikoliniearitas

b. Jika nilai $\mathrm{VIF}<10$ dan nilai tolerance value $<1$ maka tidak terjadi gejala multikoliniearitas.

Adapun hasil uji dengan menggunakan SPSS versi 24. sebagai berikut :

\begin{tabular}{|l|c|c|}
\hline \multicolumn{3}{|c|}{ TABEL 7. HASIL PENGUJIAN MULTIKOLINEARITAS } \\
DENGAN COLLINEARITY STATISTIC PRODUKTIVITAS \\
KERJA KARYAWAN SEBAGAI VARIABEL DEPENDEN \\
\hline \multirow{2}{*}{ Variabel } & \multicolumn{2}{|c|}{ Collinearity Statistics } \\
\cline { 2 - 3 } & Tolerance & VIF \\
\hline Motivasi $\left(\mathrm{X}_{1}\right)$ & 0.668 & 1.496 \\
\hline Disiplin Kerja $\left(\mathrm{X}_{2}\right)$ & 0.668 & 1.496 \\
\hline \multicolumn{3}{|c|}{ Sumber : Data primer diolah } \\
\hline
\end{tabular}

Berdasarkan hasil pengujian multikolinieritas pada tabel di atas diperoleh nilai tolerance masing-masing variabel bebas yaitu motivasi sebesar 0,668 dan disiplin kerja sebesar 0,668 , dimana kedua nilai tersebut kurang dari 1, dan nilai Variance Inflation Factor (VIF) variabel motivasi sebesar 1,496 serta disiplin kerja sebesar 1,496 dimana nilai tersebut kurang dari 10. Dengan demikian model regresi ini tidak ada multikolinearitas.

\section{Uji Autokorelasi}

Uji Autokorelasi dalam penelitian ini menggunakan Durbin Watson test dengan syarat jika nilai Durbin Watson dalam interval 1,550-2,460 maka data tidak ada gangguan autokorelasi antar variabel independen. Adapun hasil uji dengan menggunakan SPSS versi 24 . sebagai berikut:

\begin{tabular}{|l|c|c|c|c|c|}
\hline \multicolumn{7}{|c|}{ TABEL 8. UJI DURBIN-WATSON } \\
\hline Model & R & R Square & $\begin{array}{c}\text { Adjusted R } \\
\text { Square }\end{array}$ & $\begin{array}{c}\text { Std. Error of } \\
\text { the Estimate }\end{array}$ & $\begin{array}{c}\text { Durbin- } \\
\text { Watson }\end{array}$ \\
\hline 1 & $.728^{\text {a }}$ & .530 & .514 & 2.353 & 2.216 \\
\hline \multicolumn{7}{|c|}{ Sumber: Data primer diolah } \\
\hline
\end{tabular}

Berdasarkan hasil pengujian pada tabel di atas, model regresi tidak ada autokorelasi, hal ini dibuktikan dengan nilai Durbin-Watson sebesar 2.216 yang berada diantara interval 1.550 -2.460 .

\section{Uji Heteroskesdastisitas}

Uji heteroskesdastisitas dalam penelitian ini menggunakan Uji Glejser dengan syarat jika a. Jika variabel independen signifikan secara statistik atau memiliki nilai signifikansi (Sig.) $<0,05$, maka terjadi gangguan heteroskedastisitas.

b. Jika variabel independen tidak signifikan secara statistik atau memiliki nilai signifikansi (Sig.) > 0,05, maka tidak terjadi gangguan heteroskedastisitas.

Adapun hasil uji heteroskedastisitas adalah sebagai berikut:

\begin{tabular}{|c|c|c|c|c|c|c|}
\hline \multicolumn{7}{|c|}{$\begin{array}{l}\text { TABEL 9. HASIL PENGUJIAN HETEROSKESDASTISITAS } \\
\text { DENGAN UJI GLEJSER }\end{array}$} \\
\hline \multicolumn{7}{|c|}{ Coefficients $^{\mathrm{a}}$} \\
\hline \multirow{2}{*}{\multicolumn{2}{|c|}{ Model }} & \multicolumn{2}{|c|}{$\begin{array}{l}\text { Unstandardized } \\
\text { Coefficients }\end{array}$} & \multirow{2}{*}{$\begin{array}{c}\begin{array}{c}\text { Stan- } \\
\text { dardized } \\
\text { Coef- } \\
\text { ficients }\end{array} \\
\text { Beta }\end{array}$} & \multirow{2}{*}{$\mathbf{F}$} & \multirow{2}{*}{ Sig. } \\
\hline & & B & $\begin{array}{l}\text { Std. } \\
\text { Error }\end{array}$ & & & \\
\hline \multirow{3}{*}{1} & (Constant) & 5.592 & 2.150 & & 2.601 & .012 \\
\hline & Motivasi $\left(X_{1}\right)$ & -.088 & .060 & -.230 & -1.460 & .150 \\
\hline & Disiplin Kerja $\left(X_{2}\right)$ & -.014 & .061 & -.036 & -.226 & .822 \\
\hline \multicolumn{7}{|c|}{ a. Dependent Variable: RES2 } \\
\hline \multicolumn{7}{|c|}{ Sumber : Data primer diolah } \\
\hline
\end{tabular}

Berdasarkan hasil pengujian pada tabel di atas, glejser test model pada variabel motivasi $\left(\mathrm{X}_{1}\right)$ diperoleh nilai probability signifikansi 0,150 dan disiplin kerja $\left(\mathrm{X}_{2}\right)$ probability signifikansi 0,822 dimana keduanya nilai signifikansi $>0,05$. Dengan demikian regression model pada data ini tidak ada gangguan heteroskesdastisitas.

\section{HASIL ANALISIS DATA}

Pada bagian pengujian ini dimaksudkan untuk menunjukkan hasil dari pengujian atas variabel motivasi $\left(\mathrm{X}_{1}\right)$ dan disiplin kerja $\left(\mathrm{X}_{2}\right)$ terhadap produktivitas karyawan (Y). Adapun hasil analisis dalam penelitian ini sebagai berikut:

\section{Analisis Regresi Linier Berganda}

Analisis regresi berganda bertujuan untuk mengetahui seberapa besar pengaruh dari variabel bebas terhadap variabel terikat. Berdasarkan perhitungan regresi berganda menggunakan program IBM SPSS (Statistical Program for Social Science) versi 24, diperoleh hasil sebagai berikut : 


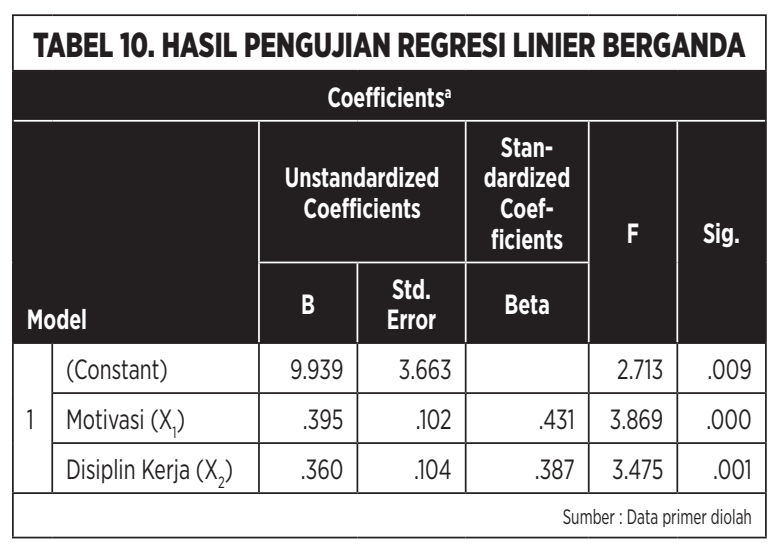

Berdasarkan hasil uji regresi berganda pada tabel di atas, diperoleh persamaan regresi $\mathrm{Y}=$ $9,939+0,395 \mathrm{X}_{1}+0,360 \mathrm{X}_{2}$. Dari persamaan di atas maka dapat disimpulkan sebagai berikut:

a. Nilai konstanta sebesar 9,939 diartikan bahwa jika variabel motivasi $\left(\mathrm{X}_{1}\right)$ dan disiplin kerja $\left(\mathrm{X}_{2}\right)$ tidak ada maka telah terdapat nilai produktivitas kerja karyawan (Y) sebesar 9,939 point.

b. Nilai 0,395 diartikan apabila konstanta tetap dan tidak ada perubahan pada variabel disiplin kerja $\left(\mathrm{X}_{2}\right)$, maka setiap perubahan 1 unit pada variabel motivasi $\left(\mathrm{X}_{1}\right)$ akan mengakibatkan terjadinya perubahan pada produktivitas kerja karyawan (Y) sebesar 0,395 point.

c. Nilai 0,360 diartikan apabila konstanta tetap dan tidak ada perubahan pada variabel motivasi $\left(\mathrm{X}_{1}\right)$, maka setiap perubahan 1 unit pada variabel disiplin kerja (X2) akan mengakibatkan terjadinya perubahan pada produktivitas kerja karyawan $(\mathrm{Y})$ sebesar 0,360 point.

\section{Analisis Koefisien Korelasi}

Analisa koefisien korelasi dimaksudkan untuk mengetahui tingkat kekuatan hubungan antara variabel independen terhadap variabel dependen. Adapun hasil pengolahan data dengan program SPSS versi 24, yaitu sebagai berikut:

\begin{tabular}{|c|c|c|c|}
\hline \multicolumn{4}{|c|}{$\begin{array}{l}\text { TABEL 11. HASIL ANALISIS KOEFISIEN KORELASI SECA } \\
\text { VARIABEL MOTIVASI(X) TERHADAP PRODUKTIVITAS K }\end{array}$} \\
\hline \multicolumn{4}{|c|}{ Correlations $^{b}$} \\
\hline & & $\begin{array}{l}\text { Motivasi } \\
\left(X_{p}\right)\end{array}$ & $\begin{array}{l}\text { Produktivitas Kerja } \\
\text { Karyawan (Y) }\end{array}$ \\
\hline \multirow{2}{*}{ Motivasi $\left(X_{1}\right)$} & $\begin{array}{l}\text { Pearson } \\
\text { Correlation }\end{array}$ & 1 & $.656^{* *}$ \\
\hline & Sig. (2-tailed) & & .000 \\
\hline \multirow{2}{*}{$\begin{array}{l}\text { Produktivitas Kerja } \\
\text { Karyawan (Y) }\end{array}$} & $\begin{array}{l}\text { Pearson } \\
\text { Correlation }\end{array}$ & $.656^{* *}$ & 1 \\
\hline & Sig. (2-tailed) & .000 & \\
\hline
\end{tabular}

Berdasarkan hasil pengujian pada tabel di atas, diperoleh nilai $R$ (koefisien korelasi) sebesar 0,656 artinya kedua variabel memiliki tingkat pengaruh atau hubungan yang kuat.

\begin{tabular}{|c|c|c|c|}
\hline \multicolumn{4}{|c|}{$\begin{array}{l}\text { TABEL 12. HASIL ANALISIS KOEFISIEN KORELASI SECARA PARSIAL ANTARA } \\
\text { VARIABEL DISIPLIN KERJA }\left(X_{2}\right) \text { TERHADAP PRODUKTIVITAS KARYAWAN (Y) }\end{array}$} \\
\hline \multicolumn{4}{|c|}{ Correlations ${ }^{b}$} \\
\hline & & $\begin{array}{c}\text { Disiplin } \\
\text { Kerja } \\
\left(\mathrm{X}_{2}\right)\end{array}$ & $\begin{array}{l}\text { Produktivitas Kerja } \\
\text { Karyawan (Y) }\end{array}$ \\
\hline \multirow{2}{*}{ Disiplin Kerja $\left(X_{2}\right)$} & $\begin{array}{l}\text { Pearson } \\
\text { Correlation }\end{array}$ & 1 & $.638^{* *}$ \\
\hline & Sig. (2-tailed) & & .000 \\
\hline \multirow{2}{*}{$\begin{array}{l}\text { Produktivitas Kerja } \\
\text { Karyawan (Y) }\end{array}$} & $\begin{array}{l}\text { Pearson } \\
\text { Correlation }\end{array}$ & $.638^{* *}$ & 1 \\
\hline & Sig. (2-tailed) & .000 & \\
\hline & & & Sumber : Data Primer diolah \\
\hline
\end{tabular}

Berdasarkan pada hasil pengujian pada tabel di atas, diperoleh nilai $R$ (koefisien korelasi) sebesar 0,638 artinya kedua variabel mempunyai tingkat pengaruh atau hubungan yang kuat.

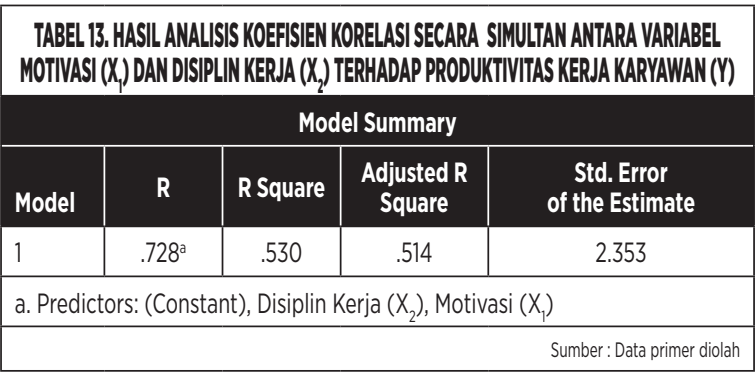

Berdasarkan pada hasil pengujian pada tabel di atas, diperoleh nilai $R$ (koefisien korelasi) sebesar 0,728 artinya variabel motivasi $\left(\mathrm{X}_{1}\right)$ dan disiplin kerja $\left(\mathrm{X}_{2}\right)$ mempunyai tingkat pengaruh atau hubungan yang kuat terhadap produktivitas kerja karyawan $(\mathrm{Y})$.

3. Analisis Koefisien Determinasi (R Square) Analisis koefisien determinasi dimaksudkan untuk mengetahui persentase kekuatan hubungan antara variabel independen terhadap variabel dependen baik secara parsial maupun simultan. Hasil pengujian koefisien determinasi yang diolah dengan program SPSS versi 24, sebagai berikut: 


\begin{tabular}{|c|c|c|c|c|}
\hline \multicolumn{5}{|c|}{$\begin{array}{l}\text { TABEL 14. HASIL ANALLISIS KOEFISIEN DETERMINASI SECARA PARSIAL } \\
\text { ANTARA VARIABELL MOTIVASI (X) TERHADAP PRODUKTIVITAS KARYAWAN (Y) }\end{array}$} \\
\hline \multicolumn{5}{|c|}{ Model Summary } \\
\hline Model & $\mathbf{R}$ & R Square & $\begin{array}{l}\text { Adjusted R } \\
\text { Square }\end{array}$ & $\begin{array}{l}\text { Std. Error } \\
\text { of the Estimate }\end{array}$ \\
\hline 1 & $.656^{\mathrm{a}}$ & .431 & .421 & 2.568 \\
\hline \multicolumn{5}{|c|}{ a. Predictors: (Constant), Motivasi $\left(X_{1}\right)$} \\
\hline & & & & Sumber : Data primer diolah \\
\hline
\end{tabular}

Berdasarkan pada hasil pengujian pada tabel di atas, diperoleh nilai $R$-square (koefisien determinasi) sebesar 0,431 maka dapat disimpulkan bahwa variabel motivasi $\left(\mathrm{X}_{1}\right)$ berpengaruh terhadap variabel produktivitas kerja karyawan $(\mathrm{Y})$ sebesar 43,1\% sedangkan sisanya sebesar $56,9 \%$ dipengaruhi oleh faktor lain.

\begin{tabular}{|c|c|c|c|c|}
\hline \multicolumn{5}{|c|}{$\begin{array}{l}\text { TABEL 15. HASIL ANALLISIS KOEFISIEN DETERMINASI SECARA PARSIAL ANTARA } \\
\text { VARIABEL DISSPLIN KERJA (X) }\left(\mathrm{X}_{2} \text { ) }\right.\end{array}$} \\
\hline \multicolumn{5}{|c|}{ Model Summary } \\
\hline Model & $\mathbf{R}$ & R Square & $\begin{array}{l}\text { Adjusted R } \\
\text { Square }\end{array}$ & $\begin{array}{l}\text { Std. Error } \\
\text { of the Estimate }\end{array}$ \\
\hline 1 & $.638^{\mathrm{a}}$ & .407 & .397 & 2.621 \\
\hline \multicolumn{5}{|c|}{ a. Predictors: (Constant), Disiplin Kerja $\left(\mathrm{X}_{2}\right)$} \\
\hline & & & & Sumber : Data primer diolah \\
\hline
\end{tabular}

Berdasarkan pada hasil pengujian pada tabel di atas, diperoleh nilai $R$-square sebesar 0,407 maka dapat disimpulkan bahwa variabel disiplin kerja $\left(\mathrm{X}_{2}\right)$ berpengaruh terhadap variabel produktivitas kerja karyawan (Y) sebesar 40,7\% sedangkan sisanya sebesar $59,3 \%$ dipengaruhi faktor lain.

\begin{tabular}{|c|c|c|c|c|}
\hline $\begin{array}{l}\text { TABELI } \\
\text { MOTIVA }\end{array}$ & $\begin{array}{l}\text { ILANA } \\
\text { DANDI }\end{array}$ & $\begin{array}{l}\text { KOEFISIEN D } \\
\text { VKERJA }(X)\end{array}$ & $\begin{array}{l}\text { ERMINASI SEC } \\
\text { RHADAP PRO }\end{array}$ & $\begin{array}{l}\text { LTAN ANTARA VARIA } \\
\text { IS KERJA KARYAWA }\end{array}$ \\
\hline & & & I Summary & \\
\hline Model & $\mathbf{R}$ & R Square & $\begin{array}{l}\text { Adjusted R } \\
\text { Square }\end{array}$ & $\begin{array}{l}\text { Std. Error } \\
\text { of the Estimate }\end{array}$ \\
\hline 1 & $.728^{\mathrm{a}}$ & .530 & .514 & 2.353 \\
\hline a. Pred & (Con & ), Disiplin & rija $\left(\mathrm{X}_{2}\right)$, Mot & \\
\hline & & & & Sumber: Data primer \\
\hline
\end{tabular}

Berdasarkan pada hasil pengujian pada tabel di atas, diperoleh nilai $R$-square sebesar 0,530 maka dapat disimpulkan bahwa variabel motivasi $\left(\mathrm{X}_{1}\right)$ dan disiplin kerja $\left(\mathrm{X}_{2}\right)$ berpengaruh terhadap variabel produktivitas kerja karyawan (Y) sebesar 53\% sedangkan sisanya sebesar $47 \%$ dipengaruhi oleh faktor lain yang tidak dilakukan penelitian.

\section{Pengujian Hipotesis}

a. Pengujian Hipotesis Secara Parsial (Uji t)

Pengujian hipotesis variabel motivasi(X1) dan disiplin kerja $\left(\mathrm{X}_{2}\right)$ terhadap produktivitas kerja karyawan (Y) dilakukan dengan uji statistik t (uji secara parsial). Dalam penelitian ini digunakan kriteria signifikansi $5 \%(0,05)$ dengan membandingkan $\mathrm{t}_{\text {hitung }}$ dengan $\mathrm{t}$ tabel yaitu sebagai berikut :

1) Jika $\mathrm{t}_{\text {hitung }}<\mathrm{t}_{\text {tabel }}$ : berarti $\mathrm{H}_{0}$ diterima dan $\mathrm{H}_{1}$ ditolak

2) Jika $\mathrm{t}_{\text {hitung }}>\mathrm{t}_{\text {tabel }}$ : berarti $\mathrm{H}_{0}$ ditolak dan $\mathrm{H}_{1}$ diterima

Kriteria dikatakan signifikan jika nilai $t_{\text {hitung }}$ $>\mathrm{t}_{\text {tabel }}$ atau $\rho$ value $<$ Sig.0,05.

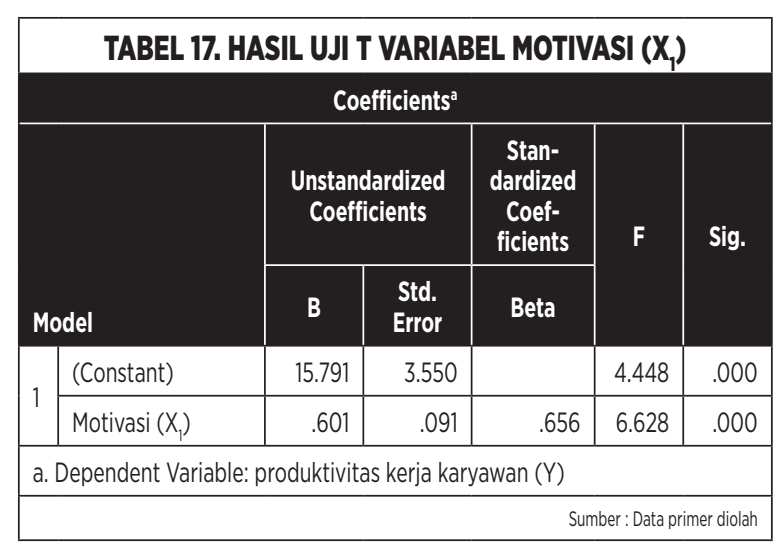

Berdasarkan pada hasil pengujian pada tabel di atas diperoleh nilai $\mathrm{t}_{\text {hitung }}>\mathrm{t}_{\text {tabel }}$ atau $(6,628>2,002)$ Hal tersebut juga diperkuat dengan nilai $\rho$ value $<$ Sig. 0,05 atau $(0,000<0,05)$. Dengan demikian maka $\mathrm{H}_{0}$ ditolak dan $\mathrm{H}_{1}$ diterima, hal ini menunjukkan bahwa terdapat pengaruh yang positif dan signifikan secara parsial antara motivasi terhadap poduktivitas karyawan.

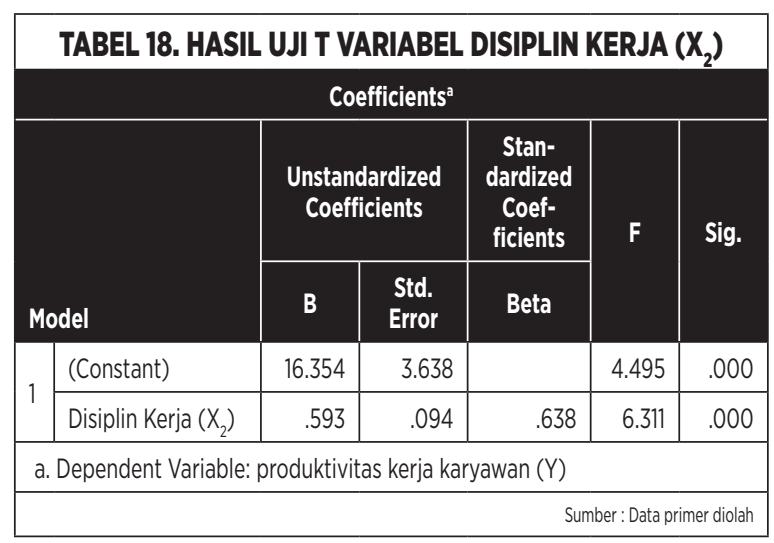

Berdasarkan pada hasil pengujian pada tabel di atas diperoleh nilai $t$ hitung $>t$ tabel 
atau $(6,311>2,002)$ Hal tersebut juga diperkuat dengan nilai $\rho$ value $<$ Sig.0,05 atau $(0,000$ $<0,05)$. Dengan demikian maka H0 ditolak dan $\mathrm{H} 2$ diterima, hal ini menunjukkan bahwa terdapat pengaruh yang positif dan signifikan secara parsial antara disiplin kerja terhadap produktivitas karyawan.

\section{b. Pengujian Hipotesis Secara Simultan (Uji F)}

Uji hipotesis pengaruh variabel motivasi dan disiplin kerja secara simultan terhadap produktivitas karyawan pada PT. Dekatama dilakukan dengan uji statistik $\mathrm{F}$ (uji simultan) dengan signifikansi 5\%. Pengujia dilakukan dengan membandingkan antara nilai $\mathrm{F}_{\text {hitung }}$ dengan $\mathrm{F}_{\text {tabel }}$ dengan ketentuan sebagai berikut:

1) Jika $\mathrm{F}_{\text {hitung }}<\mathrm{F}_{\text {tabel }}$ : berarti $\mathrm{H}_{0}$ diterima dan $\mathrm{H}_{3}$ ditolak

2) Jika $\mathrm{F}_{\text {hitung }}>\mathrm{F}_{\text {tabel }}$ : berarti $\mathrm{H}_{0}$ ditolak dan $\mathrm{H}_{3}$ diterima

Kriteria dikatakan signifikan jika nilai $\mathrm{F}_{\text {hitung }}$ $>\mathrm{F}_{\text {tabel }}$ atau $\rho$ value $<$ Sig.0,05.

\begin{tabular}{|c|c|c|c|c|c|c|}
\hline \multicolumn{7}{|c|}{ TABEL 19. HASIL HIPOTESIS (UJ F) SIMULTAN } \\
\hline \multicolumn{7}{|c|}{ ANOVA $^{a}$} \\
\hline \multicolumn{2}{|c|}{ Model } & $\begin{array}{l}\text { Sum of } \\
\text { Squares }\end{array}$ & df & $\begin{array}{l}\text { Mean } \\
\text { Square }\end{array}$ & $\mathbf{F}$ & Sig. \\
\hline \multirow{3}{*}{1} & Regression & 356.549 & 2 & 178.274 & 32.194 & $.000^{6}$ \\
\hline & Residual & 315.635 & 57 & 5.537 & & \\
\hline & Total & 672.183 & 59 & & & \\
\hline \multicolumn{7}{|c|}{ Sumber : Data primer diolah } \\
\hline
\end{tabular}

Berdasarkan pada hasil pengujian pada tabel di atas diperoleh nilai $\mathrm{F}_{\text {hitung }}>\mathrm{F}_{\text {tabel }}$ atau $(32,194>2,770)$, hal ini juga diperkuat dengan $\rho$ value $<$ Sig.0,05 atau $(0,000<0,05)$. Dengan demikian maka $\mathrm{H}_{0}$ ditolak dan $\mathrm{H}_{3}$ diterima, hal ini menunjukkan bahwa terdapat pengaruh yang positif dan signifikan secara simultan antara motivasi dan disiplin kerja terhadap produktivitas karyawan.

\section{PEMBAHASAN HASIL PENELITIAN}

\section{Pembahasan Deskriptif}

Pembahasan deskriptif, dimaksudkan untuk eksplorasi dan klarifikasi mengenai suatu fenomena atau kenyataan sosial, dengan jalan mendeskripsikan sejumlah variabel yang berkenaan dengan masalah yang diteliti.

a. Keadaan atau kriteria obyek yang diteliti berdasar pada variabel motivasi $\left(\mathrm{X}_{1}\right)$
Untuk kuesioner variabel motivasi $\left(\mathrm{X}_{1}\right)$ diperoleh rata-rata score 3.90 dengan kriteria baik. Dari kelima indikator tersebut yang mendapatkan ratting score yang paling rendah adalah pada pernyataan merasa tenang dalam bekerja karena tersedia jaminan kesehatan dari perusahaan dimana hanya mencapai score 3,78 .

b. Keadaan atau kriteria obyek yang diteliti berdasar pada variabel disiplin kerja $\left(\mathrm{X}_{2}\right)$

Untuk kuesioner variabel disiplin kerja $\left(\mathrm{X}_{2}\right)$ diperoleh rata-rata score 3.86 dengan kriteria baik. Dari kelima indikator tersebut yang mendapatkan ratting score yang paling rendah adalah pada pernyataan perusahaan memberikan balas jasa dan kesejahteraan sesuai dengan bagian dan jabatannya dimana hanya mencapai ratarata score 3,67.

c. Keadaan atau kriteria obyek yang diteliti berdasar pada variabel produktivitas karyawan (Y)

Untuk kuesioner variabel produktivitas kerja karyawan (Y) diperoleh rata-rata score 3.92 dengan kriteria baik. Dari kelima indikator tersebut yang mendapatkan ratting score yang paling rendah adalah pada pernyataan dapat menjaga ketepatan waktu dan kesempurnaan hasil pekerjaan dimana hanya mencapai score 3,75 .

\section{Pembahasan Verifikatif}

a. Pengaruh Motivasi $\left(\mathrm{X}_{1}\right)$ Terhadap Produktivitas Kerja Karyawan (Y)

Diperoleh persamaan regresi $\mathrm{Y}=$ $15,791+0,601 \mathrm{X}_{1}$ dan nilai koefisien korelasi sebesar 0,636 artinya kedua variabel mempunyai tingkat pengaruh yang kuat. Kontribusi pengaruh motivasi $\left(\mathrm{X}_{1}\right)$ terhadap produktivitas kerja karyawan $(\mathrm{Y})$ adalah sebesar 0,431 atau sebesar $43,1 \%$ sedangkan sisanya $56,9 \%$ dipengaruhi oleh faktor lain. Hal ini menunjukkan bahwa motivasi yang meningkat akan meningkatkan poduktivitas karyawan. Uji hipotesis diperoleh $\mathrm{t}_{\text {hitung }}>\mathrm{t}_{\text {tabel }}$ atau $(6,628>$ 2,002), hal ini diperkuat dengan probability signicancy $0,000<0,05$, dengan demikian $\mathrm{H}_{0}$ ditolak dan $\mathrm{H}_{1}$ diterima artinya terdapat pengaruh yang positif dan signifikan secara parsial antara motivasi terhadap produktivitas karyawan. 
b. Pengaruh Disiplin Kerja $\left(\mathbf{X}_{2}\right)$ Terhadap Produktivitas Kerja Karyawan (Y)

Diperoleh persamaan regresi $\mathrm{Y}=$ $16,354+0,593 X$ dan nilai koefisien korelasi sebesar 0,638 artinya kedua variabel mempunyai tingkat pengaruh yang kuat. Kontribusi pengaruh disiplin kerja $\left(\mathrm{X}_{2}\right)$ terhadap produktivitas kerja karyawan (Y) adalah sebesar 0,407 atau sebesar 40,7\% sedangkan sisanya 59,3\% dipengaruhi oleh faktor lain. Hal ini menunjukkan bahwa disiplin kerja yang tinggi akan meningkatkan produktivitas kerja karyawan. Uji hipotesis diperoleh $\mathrm{t}_{\text {hitung }}>\mathrm{t}_{\text {tabel }}$ atau $(6,311>2,002)$, hal ini diperkuat dengan probability signicancy $0,000<0,05$, dengan demikian $\mathrm{H}_{0}$ ditolak dan $\mathrm{H}_{2}$ diterima artinya terdapat pengaruh yang positif dan signifikan secara parsial antara disiplin kerja terhadap produktivitas karyawan.

c. Pengaruh Motivasi $\left(\mathrm{X}_{1}\right)$ dan Disiplin Kerja $\left(\mathrm{X}_{2}\right)$ Secara Simultan Terhadap Produktivitas Karyawan (Y).

Diperoleh persamaan regresi $Y=9,939$ $+0,395 \mathrm{X}_{1}+0,360 \mathrm{X}_{2}$. Hasil analisis regresi ini menunjukkan koefisien dari masingmasing variabel bertanda positif, artinya semakin tinggi platihan dan disiplin kerja, maka akan semakin tinggi pula produktivitas kerja karyawan, sebaliknya semakin rendah motivasi dan disiplin kerja, maka akan semakin rendah pula produktivitas kerja karyawan. Sedangkan tingkat hubungannya atau pengaruh antara variabel bebas dengan variabel terikat diperoleh sebesar 0,728 artinya memiliki memiliki hubungan atau pengaruh yang kuat. Kontribusi pengaruh motivasi dan disiplin kerja sebesar 53,0\% sedangkan sisanya sebesar $37 \%$ dipengaruhi oleh faktor lain. Uji hipotesis diperoleh $\mathrm{F}_{\text {hitung }}>$ $\mathrm{F}_{\text {tabel }}$ atau $(32,194>2,770)$, hal tersebut juga diperkuat dengan probability significancy $0,000<0,05$. Dengan demikian $\mathrm{H}_{0}$ ditolak dan $\mathrm{H}_{3}$ diterima. Artinya terdapat pengaruh positif dan signifikan secara simultan antara motivasi dan disiplin kerja terhadap produktivitas karyawan.

\section{KESIMPULAN DAN SARAN \\ Kesimpulan}

Berdasarkan uraian pada bab-bab sebelumnya, dan dari hasil analisis serta pembahasan mengenai pengaruh motivasi dan disiplin kerja terhadap produktivitas kerja karyawan, sebagai berikut:

1. Motivasi berpengaruh positif dan signifikan terhadap produktivitas karyawan dengan korelasi sebesar 0,636 artinya memiliki pengaruh yang kuat dengan kontribusi pengaruh sebesar $43,1 \%$. Uji hipotesis diperoleh $\mathrm{t}_{\text {hitung }}>\mathrm{t}_{\text {tabel }}$ atau $(6,628>2,002)$, hal ini diperkuat dengan probability 0,000 $<0,05$, dengan demikian $\mathrm{H}_{0}$ ditolak dan $\mathrm{H} 1$ diterima artinya terdapat pengaruh yang positif dan signifikan antara motivasi terhadap produktivitas karyawan.

2. Disiplin kerja berpengaruh positif dan signifikan terhadap produktivitas karyawan dengan korelasi sebesar 0,638 artinya memiliki pengaruh yang kuat dengan kontribusi pengaruh sebesar $40,7 \%$. Uji hipotesis diperoleh $\mathrm{t}_{\text {hitung }}>\mathrm{t}_{\text {tabel }}$ atau $(6,311>$ 2,02), hal ini diperkuat dengan probability $0,000<0,05$, dengan demikian $\mathrm{H}_{0}$ ditolak dan $\mathrm{H}_{2}$ diterima artinya terdapat pengaruh yang positif dan signifikan antara disiplin kerja terhadap produktivitas karyawan.

3. Motivasi dan disiplin kerja berpengaruh positif dan signifikan terhadap produktivitas karyawan dengan persamaan regresi $\mathrm{Y}=9,939+0,395 \mathrm{X}_{1}+0,360 \mathrm{X}_{2}$. Semakin tinggi motivasi dan disiplin kerja maka produktivitas karyawan akan semakin meningkat. korelasi atau tingkat hubungannya antara variabel bebas dengan variabel terikat sebesar 0,728 artinya memiliki hubungan atau pengaruh yang kuat dengan kontribusi pengaruh secara simultan sebesar 53\%. Uji hipotesis diperoleh nilai $\mathrm{F}_{\text {hitung }}>\mathrm{F}_{\text {tabel }}$ atau $(32,194>$ 2,770), hal tersebut juga diperkuat dengan probability $0,000<0,05$. Dengan demikian $\mathrm{H}_{0}$ ditolak dan $\mathrm{H}_{3}$ diterima. Artinya terdapat pengaruh positif dan signifikan secara simultan antara motivasi dan disiplin kerja terhadap produktivitas karyawan.

\section{Saran.}

1. Variabel motivasi, indikator yang paling lemah adalah kebutuhan rasa aman ter- 
utama pada pernyataan merasa tenang dalam bekerja karena tersedia jaminan kesehatan dari perusahaan dimana hanya mencapai score 3,78 meskipun termasuk dalam kategori baik namun mengingat motivasi kerja juga merupakan salah satu variabel penting dalam memaksimalkan produktivitas kerja perusahaan maka perusahaan harus mendorong semua karyawan agar dapat menentukan prioritas kerja dan memberi kesempatan pada karyawan untuk dipromosikan ke bagian yang lebih tinggi ketika memang memiliki skill dan kemampuan yang baik. Dengan demikian, karyawan yang termotivasi akan melakukan usaha yang lebih besar, memiliki kecakapan dalam menunjang aktivitas pekerjaannya.

2. Variabel disiplin, indikator yang paling lemah adalah balas jasa terutama pada pernyataan perusahaan memberikan balas jasa dan kesejahteraan sesuai dengan bagian dan jabatannya dimana hanya mencapai score 3,67 meskipun termasuk dalam kategori baik namun mengingat disiplin juga merupakan salah satu variabel penting dalam memaksimalkan produktivitas kerja perusahaan harusbenar-benarmemberikan apa yang menjadi hak karyawan dengan mencover jaminan kesehatan dan asuransi lainnya sehingga karyawan merasa tenang dalam menjalankan aktiivitas kerjanya

3. Variabel produktivitas kerja karyawan, indikator yang paling lemah adalah Indikator Mempunyai kontribusi positif pada perusahaan terutama pada pernyataan ketepatan waktu dan kesempurnaan hasil pekerjaan dimana hanya mencapai score 3,75 meskipun termasuk dalam kategori baik namun mengingat produktivitas kerja karyawan juga merupakan salah satu variabel penting dalam kinerja perusahaan secara keseluruhan, maka perusahaan harus mendorong karyawan memiliki integritas dalam mencapai performa kerja yang sebaik-baiknya agar kesemuanya dapat menunjang bidang pekerjaan masing-masing bagian kerja.

4. Kontibusi pengaruh motivasi dan disiplin kerja secara simultan terhadap produktivitas kerja karyawan sebesar 53\%, nilai ini masih bisa ditingkatkan dengan secara selektif dapat memprioritaskan pesanan pelanggan yang harus dipenuhi dan kondisi masing-masing variabel bebas harus ditingkatkan secara signifikan. Oleh karenanya disarankan kepada penelitian berikutnya agar melakukan penelitian yang relevan dengan cara memperbaiki indikator yang masih tidak baik atau dengan menambah indikator pertanyaan dan jumlah responden penelitian sehingga akan dapat lebih diketahui variabel yang paling memberikan kontribusi positif bagi perusahaan.

\section{DAFTAR PUSTAKA}

A.A Anwar Prabu Mangkunegara, "Sumber Kerangka Berpikir Kinerja”. Gramedia, Jakarta Selatan, 2014.

Agung Nugroho, "Strategi Jitu Dalam Memilih Metode Statistik Peneltian", Andi, Yogyakarta, 2012.

Algifari, "Analisis Regresi", Yogyakarta, 2011.

Arikunto, Suharsimi, "Prosedur Penelitian Suatu Pendekatan Praktek", PT. Rineka Cipta, Jakarta, 2015.

Bernardin, H. John dan Joyce E.A. Russell, "Human Resource Management", An Experiential Approach, McGrow Hill, Singapore, 2013.

Bilson Simamora "Panduan Riset Prilaku Konsumen", PT. Gramedia Pustaka, Jakarta, 2012.

Dessler, Gerry, "Human Resources Management", Prenticehall, International Inc, London, 2014.

Edi Sutrisno, "Sumber Daya Manusia", PT. Gramedia, Surabaya, 2012.

Edwin B Flippo, "Prinsip-Prinsip Sumber Daya Manusia”, Edisi ke Duabelas, Erlangga, Jakarta, 2014.

Follet dalam Sule, "Pengantar Manajemen", Kencana, Jakarta, 2014.

G.R. Terry, and Rue, Leslie W. Rue, "Dasardasar Manajemen”, Bumi Aksara, Jakarta 2014.

Ghozali, Imam, "Aplikasi Analisis Multivariate dengan Program SPSS", Edisi Kelima, Badan Penerbit Undip, Semarang, 2014.

Handoko, "Manajemen Personalia dan Sumberdaya Manusia", Edisi Kelima, BPFE UGM, 
Yogyakarta, 2012.

Hasibuan, "Sumber Daya Manusia", Haji Masagung, Jakarta, 2016.

Istijianto, "Aplikasi Praktis Riset Pemasaran", Gramedia Pustaka Utama, Jakarta, 2012.

Jonathan Sarwono, "Metode Penelitian Kuantitatif Dan Kualitatif”, Graha Ilmu, Yogyakarta, 2012

Luthans, Fred, "Organizational Behavior", McGraw-Hill, New York, 2012.

Mathis, Robert L dan John H. Jackson. "Manajemen Sumber Daya Manusia", Buku Dua. Salemba Empat: Jakarta, 2014.

Michael R Carrell, "Human Resourcee Managemen Global for managing Diverse Wokplace", Edition, Prenice Hall Inc. Nre Jersey, 2015.

Miftah Thoha "Kepemimpinan Dalam Manajemen”, Edisi Pertama, PT. Raja Grafindo, Jakarta, 2012.

Panji Anoraga, "Psikologi Kerja", Rineka Cipta, Jakarta, 2014.

Rivai, Veithzal, "Manajemen Sumber Daya Manusia Untuk Perusahaan", Raja Grafindo Persada, Jakarta, 2013.

Robbins, Stephen dan Mary Coulter, "Manajemen", PT. Indeks Kelompok Gramedia, Jakarta, 2012.

Safroni Ladzi, "Manajemen dan Reformasi Pelayanan Publik dalam Konteks Birokrasi Indonesia", Aditya Media Publishing, Surabaya 2012 .

Salam, "Manajemen Pemerintahan Indonesia". PT. Djambatan, Jakarta, 2014.

Santoso, Singgih, "SPSS Statistik Parametik" Cetakan Kedua, PT. Elek Media, 2015.

Sarwono, Jonathan, "Metode Penelitian Kuantitatif Dan Kualitatif”, Graha Ilmu, Yogyakarta, 2012

Sedarmayanti. "Manajemen Sumber Daya Manusia, Reformasi Birokrasi dan Manajemen Pegawai Negeri Sipil", Cetakan Kelima, PT Refika Aditama, Bandung, 2014.

Siagian Sondang P, "Kiat Meningkatkan Produktivitas Kerja”, PT. Rineka Cipta, Jakarta, 2012.

Simamora, Bilson, "Panduan Riset Dan Perilaku Konsumen”, PT. Gramedia Pustaka Utama, Jakarta, 2014.

Singgih Santoso, "SPSS Statistik Parametik" Cetakan Kedua, PT. Elek Media, Jakarta, 2013.
Siswanto dan Agus, "Manajemen Sumber Daya Manusia” PT. Gramedia Pustaka, Jakarta, 2013.

Sudjana, "Metode Statistika", Edisi Keenam, Tarsito, Bandung, 2011.

Sugiyono, "Metode Penelitian Kuantitatif Kualitatif dan $R$ \& D", Penerbit CV. Alfabeta, Bandung, 2016.

Suharsimi Arikunto, "Prosedur Penelitian Suatu Pendekatan Praktek”, PT. Rineka Cipta, Jakarta, 2013.

Supranto, "Statistik Teori dan Aplikasi", Pustaka Ekonomi, Jakarta, 2013.

Sutrisno, Edi., 2014. "Pengaruh Disiplin kerja dan Budaya Organisasi Terhadap Kinerja Karyawan Devisi Radiologi RSUD Karidi Semarang" Vol. 12 No.2.

Tb. Sjaftri Mangkuprawira (2010:135) "Pengertian Pelatihan". Gramedia, Jakarta Pusat, 2014.

Terry, George R \& Rue, Leslie W. Rue, "DasarDasar Manajemen", Jakarta Bumi Aksara, Jakarta, 2010.

Thomas S. dan Snell, Scott A, "Management The New Competitive", Landscape. Sixth Edition. McGraw Hill. New York, 2013.

Veithzal Rivai, "Proses Arti Pelatihan". Jakarta, 2014.

W.F. Cascio dalam Robbins, "Managing Human resources productivity of Work", Edisi ketujuh, terjemahan, Jakarta, 2012.

Wawan S. Suherman, "Kurikulum Berbasis Kompetensi Pendidikan Jasmani Teori dan Praktik Pengembangan", FIK UNY, Yogyakarta, 2013.

Wibowo, "Manajemen Kinerja", PT. Raja Grafindo Persada, Jakarta, 2014.

Windy Aprilia dan Gunasti Hudiwinarsih. 2014. "Pengaruh Kompensasi, Motivasi dan Komitmen Organisasi Terhadap Kinerja Karyawan bagian Akuntansi (Studi Kasus Pada Perusahaan manufaktur di Surabaya). The Indonesian Accounting Review. Volume 2, No. 2, Juli. Pages 215-228. 